Chronic Obstructive Pulmonary Diseases: Journal of the COPD Foundation

\title{
Review
}

\section{Exacerbations of Lung Disease in Alpha-1 Antitrypsin Deficiency}

\author{
Daniel J. Smith ${ }^{1}$ Paul R. Ellis, $\mathrm{MBChB}^{1}$ Alice M. Turner, MRCP, PGCE (MedEd), PhD ${ }^{1,2}$
}

\begin{abstract}
Alpha-1 antitrypsin deficiency (AATD) is an important risk factor for development of chronic obstructive pulmonary disease (COPD). Patients with AATD classically develop a different pattern of lung disease from those with usual COPD, decline faster and exhibit a range of differences in pathogenesis, all of which may be relevant to phenotype and/or impact of exacerbations. There are a number of definitions of exacerbation, with the main features being worsening of symptoms over at least 2 days, which may be associated with a change in treatment. In this article we review the literature surrounding exacerbations in AATD, focusing, in particular, on ways in which they may differ from such events in usual COPD, and the potential impact on clinical management.
\end{abstract}

\begin{abstract}
Abbreviations: alpha-1 antitrypsin, AATD; chronic obstructive pulmonary disease, COPD; alpha-1 antitrypsin, AAT; neutrophil elastase, NE; acute exacerbation of chronic obstructive pulmonary disease, AECOPD; tumour necrosis factor alpha, TNF-a; C-reactive protein, CRP; interleukin-1 beta, IL-1ß; interleukin-8, IL-8; potentially pathogenic microorganisms, PPM; cystic fibrosis, CF; interleukin-6, IL-6; leukotriene B-4, LTB4; mydoperoxidase, MPO; Z-protein, Z-AAT; TNF-a converting enzyme, TACE; reactive oxygen species, ROS; Human rhinovirus, HRV; interquartile range, IQR; oral corticosteroids, OCSs; odds ratio, OR; confidence interval, CI; EXAcerbation and Computed Tomography Scan in Lung Endpoints trial, EXACTLE; inhaled corticosteroids, ICSs; pulmonary rehabilitation, PR

Funding Support: DJS is supported by a grant from the British Lung Foundation; PRE is supported by grants from the Alpha-1 Foundation and the American Thoracic Society (ATS) Foundation; AMT has current grant funding from NIHR, Health Foundation, the Alpha-1 Foundation, the ATS Foundation, AstraZeneca, CSL Behring and Chiesi.

Date of Acceptance: September 18, 2020 | Published Online Date: November 19, 2020

Citation: Smith DJ, Ellis PR, Turner AM. Exacerbations of lung disease in alpha-1 antitrypsin deficiency. Chronic Obstr Pulm Dis. 2021;8(1):162-176. doi: https://doi.org/10.15326/jcopdf.2020.0173
\end{abstract}

\begin{abstract}
1 Institute of Applied Health Research, University of Birmingham, Birmingham, United Kingdom

2 University Hospitals Birmingham, United Kingdom
\end{abstract}

\section{Address correspondence to:}

Alice M. Turner

Email: a.m.turner@bham.ac.uk

Phone: +44 (0) (121) 371-3885

\section{Keywords:}

chronic obstructive pulmonary disease; COPD; alpha-1

antitrypsin deficiency; exacerbation; emphysema; neutrophil

\section{Introduction}

Alpha-1 antitrypsin deficiency (AATD) is an inherited disorder characterized by reduced levels of serum alpha-1 antitrypsin (AAT), a protease inhibitor. The imbalance between proteases and anti- proteases, respectively neutrophil elastase (NE) and AAT, together with the effect of polymerized AAT, predisposes affected patients to a spectrum of lung and liver diseases. ${ }^{1}$ Respiratory manifestations of AATD classically involve basal panacinar emphysema, though chronic bronchitis and bronchiectasis are also recognized. ${ }^{2-4}$ AATD is well-documented as a predisposing factor to the development of chronic obstructive pulmonary disease (COPD). ${ }^{2}$ In contrast to non-AAT-deficient (usual) COPD, AATD COPD patients typically present at a younger age with a severity of lung dysfunction that is out of proportion to the relatively mild smoking burden, albeit with the same features of breathlessness, chronic cough and regular sputum production.

Patients with AATD COPD are known to experience acute exacerbations of COPD (AECOPD), defined 
as an acute worsening of respiratory symptoms that results in additional therapy. ${ }^{5}$ These events are common and typically manifest as a deviation from usual sputum volume, sputum purulence and breathlessness, lasting approximately 2 weeks on average. ${ }^{6,7}$ Exacerbations in AATD are demonstrated to have a detrimental impact on disease progression and quality of life. ${ }^{8-10}$ Despite this, evidence surrounding exacerbation in AATD is very limited, especially relating to the acute management and prevention of exacerbations in AATD. The only AATD-specific treatment, AAT augmentation therapy, is capable of reducing lung function decline, but in meta-analysis of randomized controlled trial data has been controversially demonstrated to associate with an increase in exacerbation rates. ${ }^{11}$ Current management of exacerbations is based on limited evidence, alongside the assumption of transferable mechanisms in usual COPD. However, exacerbations of AATD are both biochemically and clinically dissimilar to usual COPD and it is possible that AATD may benefit from distinct management and prevention strategies. ${ }^{7,12,13}$

Controlling the frequency and severity of exacerbations in AATD, and the management thereof, could have a positive impact on the quality of life, disease progression and prognosis of affected patients. This article reviews the evidence base for decision making about acute exacerbation management and exacerbation risk reduction specific to AATD patients.

\section{Causes of Exacerbations}

The etiology of COPD exacerbations can be broadly classified into infective and non-infective. In usual COPD, viral, bacterial and viral-bacterial coinfections cause $23 \%, 29 \%$ and $25 \%$ of infective hospitalized exacerbations respectively. ${ }^{14}$ Noninfective exacerbations are estimated to comprise $28 \%$ of exacerbations and result from a variety of stimuli, including atmospheric pollution, seasonal variation, pulmonary embolus and congestive cardiac failure. ${ }^{14-18}$ Many exacerbations are also of unknown origin. Surprisingly, in AATD COPD, exacerbation etiology has rarely been reported, permitting only limited inferences to be made about differences from usual COPD.

\section{Infective Exacerbations}

Bacterial Events and Bacterial Colonization

Mechanisms for bacterial exacerbation in COPD include acquisition of new bacterial strains and expansion of stable bacterial colonies within the tracheobronchial tree. Bacteria implicated in infective exacerbations of AATD include Haemophilus influenzae, Moraxella catarrhalis and Streptococcus pneumoniae. ${ }^{12}$ It is not clear if this relates to new acquisition or expansion of stable bacterial colonies; however, isolation of new strains of these bacteria in usual COPD are associated with a significantly increased risk of an exacerbation. ${ }^{19}$ Isolation of newly acquired $\mathrm{H}$ influenzae at exacerbation is reported to associate with greater forced expiratory volume in 1 second $\left(F E V_{1}\right)$ decline than $\mathrm{H}$ influenzaeassociated exacerbations in patients with pre-existing colonization. ${ }^{20}$ This may relate to significantly greater increases in sputum concentrations of $\mathrm{NE}$, tumor necrosis factor alpha (TNF-a) and serum C-reactive protein ( $\mathrm{CRP}$ ) in exacerbations attributed to new bacterial acquisition compared to infective exacerbations of an alternate nature. ${ }^{21}$ Purified human AAT has been shown in vitro to significantly inhibit bacterial endotoxin-induced TNF-a and interleukin-1 beta (IL-1 $\beta$ ) release by monocytes and interleukin- 8 (IL-8) release by neutrophils in a concentrationdependent manner, suggesting a role for AAT in prohibiting excess bacterial-driven inflammation. ${ }^{22}$ Since NE and TNF-a are elevated in stable AATD, acquisition of new bacterial strains in the absence of sufficient AAT may lead to excessive cumulative increases in inflammation which may be contributary to exacerbation pathogenesis. ${ }^{13}$

Approximately two-thirds of patients with AATD are reported to exhibit lower airway bacterial colonization by potentially pathogenic microorganisms (PPM), compared to $29 \%-52 \%$ in usual COPD. ${ }^{23-26}$ Lower airway bacterial colonization is demonstrated to relate to increased exacerbation frequency $(p=0.023)$, which may relate to the positive correlation between airway bacterial load and concentration of pulmonary inflammatory mediators $(p<0.05) .{ }^{23,27}$ Conversely, individuals with AATD have been observed to exhibit significantly lower total bacterial loads (as measured by $16 S$ sequencing) in stable state sputum samples compared to usual COPD $(p=0.008)$, including significantly decreased levels of Moraxella catarrhalis and Streptococcus pneumoniae $(p=0.012$ and $p=0.001$, 
respectively). ${ }^{28}$ After adjustment for lung function, Rosell et al observed that only positive cultures with a high PPM load are associated in a dose-dependent manner with exacerbation occurrence $(p=0.005)$, supporting the concept of a theoretical threshold for minimum bacterial load beyond which inflammation may manifest in clinical features of exacerbation. ${ }^{24,29}$ This may suggest a lesser contribution of PPM expansion in the etiology of AECOPD in AATD. One large scale study is currently underway which may provide insight in this area. ${ }^{30}$

Radiological bronchiectasic changes have been observed in up to $94 \%$ of individuals with AATD, although these changes were determined to be clinically significant in only $27 \%$ of patients. ${ }^{3}$ Coexistence of bronchiectasis in COPD is associated with an increased prevalence of colonization and higher rates of Pseudomonas aeruginosa isolation. ${ }^{31}$ Due to the relatively high NE burden shared by cystic fibrosis (CF)and AATD, it is conceivable that the conditions may have a synergistic effect on airway disease and colonization. ${ }^{32}$ However, studies investigating this have reported contradicting outcomes in mild AAT phenotypes; it has not been tested in PiZZ phenotype individuals. ${ }^{33-35}$ Accordingly, it is not clear if other CF-typical microbes may play a causative role in exacerbations of AATD.

\section{Viral Events}

As in usual COPD, viral and viral-bacterial coinfections may account for a significant proportion of exacerbations in AATD. However, there is not enough evidence reported at this stage to be able to make useful inferences regarding viral etiology in AATD, though there is much data in usual COPD. ${ }^{36}$

\section{Non-infective Exacerbations}

Non-infective exacerbations have not been reported on in AATD. Air pollutants are implicated in disease progression in AATD and it is plausible that they may comprise a further role in pathogenesis of noninfective exacerbations, as in usual COPD, due to the increase in pulmonary chemokines including IL-8 and interleukin-6 (IL-6). ${ }^{37-39}$ In usual COPD populations, depression and cardiovascular disease are related to exacerbation frequency. ${ }^{40}$ Analysis of a large population-based database revealed significantly lower prevalence of ischemic heart disease and depression in AATD compared to usual COPD, which could suggest a lower incidence of comorbidity-related exacerbations in AATD. ${ }^{41}$

\section{Inflammatory Effects}

A major change between stable COPD and exacerbated COPD is the difference in airway inflammation. In particular, COPD exacerbations are associated with elevated neutrophils, which are considered a key driver of airway inflammation in exacerbations and related to exacerbation severity. ${ }^{14,42,43}$ Mechanisms mediating concentrations and/or activity of neutrophils and other inflammatory mediators may be critical for understanding the differences in pathogenesis between usual and deficient exacerbations.

\section{Leukotriene B-4 and Interleukin-8}

In the setting of AATD COPD, elevated NE contributes to a pro-inflammatory milieu within the airways (Figure 1). NE acts on alveolar macrophages and bronchial epithelial cells to induce release of potent neutrophil chemoattractants leukotriene B4 (LTB4) and interleukin-8 (IL-8, CXCL8) respectively. ${ }^{44-46}$ AAT also abrogates IL-8 and LTB4-mediated neutrophil chemotaxis by up to $40 \%$, independently of anti-protease activity, potentially via direct binding and inhibition. ${ }^{47-49}$ Consequently in AATD COPD, both the concentration and contribution to sputum chemotactic activity of LTB4 and IL-8 are significantly greater than in usual COPD. ${ }^{12,50-52} \mathrm{IL}-8$ concentration is observed to be significantly higher in frequent, compared to infrequent, exacerbators $(p=0.001)$ and may be causative in this respect. ${ }^{27}$

Increases in LTB4 and IL-8 at exacerbation are significantly higher in AATD than usual COPD ( $p=0.02$ and $p=0.01$, respectively), although parallel rises in myeloperoxidase (MPO) at exacerbation are often not reported to be significantly different between the 2 groups, which is unexpected. ${ }^{12,53}$ It is plausible that there are additional mechanisms of proinflammatory neutrophilic modulation in usual COPD, including aberrant neutrophil migration, which has been demonstrated to increase inflammation in non-deficient individuals. ${ }^{54}$ Additionally, $Z$ protein (Z-AAT) formation, polymerization and accumulation within neutrophils can enhance neutrophil apoptosis, and could, theoretically, contribute to a relatively supressed chemotactic response in AATD individuals during exacerbation. ${ }^{55}$ 


\section{Figure 1. Effects of Alpha-1 Antitrypsin on Key Pulmonary Inflammatory Pathways}

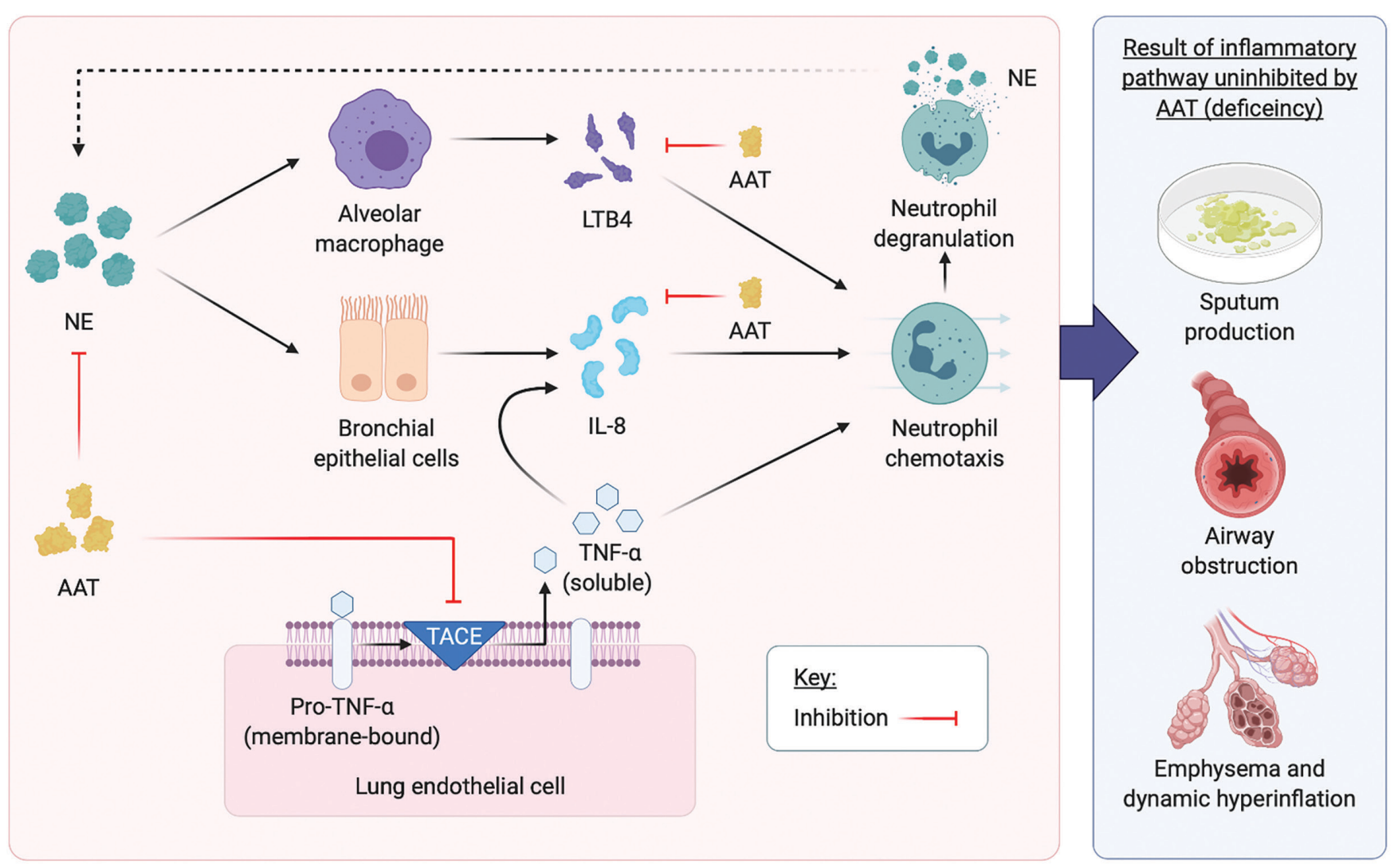

$\mathrm{NE}=$ neutrophil elastase; AAT=alpha-1 antitrypsin; LTB4=leukotriene-B4; IL-8=interleukin-8; TNF- $\alpha=$ tumour necrosis factor- $\alpha$; TACE $=$ TNF- $\alpha$ converting enzyme

\section{Tumor Necrosis Factor-Alpha}

AAT modulates the release and activity of proinflammatory cytokine TNF-a (Figure 1). Active TNF-a is a principal driver of inflammation in AECOPD with sputum concentrations observed to elevate more than fourfold during exacerbations of usual COPD. ${ }^{56}$ TNF-a facilitates leucocyte and neutrophil migration to the bronchial mucosa, stimulates neutrophil degranulation and superoxide production and upregulates IL-8 release. ${ }^{57-59}$ Sputum concentrations of TNF-a are observed to elevate more than fourfold during exacerbations of usual COPD compared to stable state $(p=0.01)$, correlating with the percentage of neutrophils present within induced sputum samples. Application of AAT to neutrophils, airway macrophages and endothelial cells results in decreased TNF-a secretion. ${ }^{13,52,60}$ Inhibition of TNF-a secretion occurs by AAT-induced inhibition of the TNF-a converting enzyme (TACE) on the membrane surface, which is responsible for cleavage of pro-TNF-a to the soluble active form. ${ }^{13,49}$ Deficient
AAT during exacerbation may permit dysregulated action and release of TNF-a within the pulmonary microenvironment, capable of promoting clinical features of exacerbation. ${ }^{12}$ Future investigations of TNF-a concentrations during exacerbations of AATD may inform the provision of TNF-a targeted therapies, which to date, have only been investigated in usual COPD. ${ }^{61}$

AAT has other anti-inflammatory effects (Table 1), ${ }^{62-76}$ however, these have not been investigated in the context of exacerbation, or even stable COPD in some cases.

\section{Intrinsic Neutrophil Properties}

Recent data suggests neutrophils isolated from patients in AATD may also differ intrinsically from those in usual COPD. ${ }^{77}$ Murphy et al report that neutrophils isolated from AATD individuals have an increased quantity and activity of neutrophil primary granule proteins in the membrane proteome when compared to usual COPD. In response to stimulation, 


\section{Table 1. Table Describing Additional Inflammatory Modulating Effects of Alpha-1 Antitrypsin and Implication in Alpha-1 Antitrypsin Deficiency}

\begin{tabular}{|c|c|c|c|}
\hline Molecule & Action of Molecule & $\begin{array}{l}\text { Action of AAT } \\
\text { on Molecule }\end{array}$ & $\begin{array}{l}\text { Possible Result of AAT } \\
\text { Deficiency on This Interaction }\end{array}$ \\
\hline Calpain I & $\begin{array}{l}\text { Promote directional neutrophil } \\
\text { migration toward chemotactic } \\
\text { stimuli }^{62}\end{array}$ & Inhibition of Calpain $\mathrm{I}^{63}$ & $\begin{array}{l}\text { Promote efficient neutrophil migration, } \\
\text { capable of promoting acute and chronic } \\
\text { inflammation }^{64}\end{array}$ \\
\hline Free Haem & $\begin{array}{l}\text { Neutrophil activation. } \\
\text { Amplification of inflammatory } \\
\text { response and oxidative stress }\end{array}$ & $\begin{array}{l}\text { AAT acts as a free haem } \\
\text { scavenger }^{66}\end{array}$ & $\begin{array}{l}\text { Increased neutrophilic activation and } \\
\text { inflammation including IL- } 8 \text { release and } \\
\text { ROS production }^{66}\end{array}$ \\
\hline Gelatinase B & $\begin{array}{l}\text { Mediates neutrophil migration } \\
\text { into airway }^{67}\end{array}$ & Inhibition of Gelatinase $B^{55}$ & $\begin{array}{l}\text { Increased neutrophil infiltration into } \\
\text { airways }\end{array}$ \\
\hline $\begin{array}{l}\text { High-density } \\
\text { Lipoprotein }\end{array}$ & $\begin{array}{l}\text { Reduces neutrophilic } \\
\text { inflammation }^{68}\end{array}$ & $\begin{array}{l}\text { AAT forms a complex with } \\
\text { HDL which provides a } \\
\text { greater reduction in } \\
\text { neutrophilic and cytokine- } \\
\text { driven (TNF-a, MCP-1, IL-1 } 3 \text { ) } \\
\text { inflammation when } \\
\text { compared to HDL or AAT } \\
\text { alone }\end{array}$ & $\begin{array}{l}\text { Reduced protective effect of HDL against } \\
\text { neutrophilic and cytokine-driven } \\
\text { inflammation } 68\end{array}$ \\
\hline IL-1及 & $\begin{array}{l}\text { Pro-inflammatory cytokine. } \\
\text { Potent activator of alveolar } \\
\text { macrophages } \\
\text { Stimulates production of } \\
\text { neutrophil chemoattractants }\end{array}$ & Inhibition of IL-1 $\beta^{22}$ & Increased neutrophilic inflammation \\
\hline $\begin{array}{l}\text { Oxidized } \\
\text { Methionine } \\
\text { Residues on } \\
\text { AAT }\end{array}$ & $\begin{array}{l}\text { Act as anti-oxidant, controlling } \\
\text { levels of neutrophil released } \\
\text { ROS and reducing oxidant- } \\
\text { driven amplification of lung } \\
\text { inflammation }\end{array}$ & $\mathrm{n} / \mathrm{a}$ & $\begin{array}{l}\text { Increased neutrophil ROS } \\
\text { Increased oxidant driven lung inflammation }\end{array}$ \\
\hline
\end{tabular}

AAT=alpha- 1 antitrypsin; ROS=reactive oxygen species; PR3=proteinase-3; IL-1 $\beta=$ interleukin- $1 \beta$; TNF- $\alpha=$ tumour necrosis factor- $\alpha$; $\mathrm{HDL}=$ high-density lipoprotein; MCP-1=monocyte chemoattractant protein-1

neutrophils isolated from AATD individuals mounted a significantly greater reactive oxygen species (ROS) and NE response compared to FEV 1 -matched COPD controls. ${ }^{77}$ These findings may be relevant in exacerbation pathogenesis. However, the sample size of the study was small ( $\mathrm{n}=6$ patients per cohort), so results should be viewed with caution. ${ }^{77}$

\section{Clinical Features}

\section{Presentation of Exacerbations}

The classical study by Anthonisen et al recognized 3 major symptoms in AECOPD; deviation in sputum purulence, sputum volume and dyspnea and categorized exacerbations as type 1 when all 
3 major symptoms deteriorated, type 2 if only 2 major symptoms deteriorated and type 3 when 1 of 3 major symptoms deteriorated in combination with symptoms of an upper respiratory tract infection including wheeze and cough. ${ }^{6}$ Vijayasaratha and Stockley demonstrated through diary card analysis that type 1, 2 and 3 exacerbations account for 34\%, $32 \%$ and $14 \%$ of total exacerbations in a cohort of patients with AATD COPD, with the remaining $20 \%$ of exacerbations defined by 1 major symptom with no minor symptoms. ${ }^{7}$ However, a previous investigation in AATD suggested that the proportion of severe exacerbations may be much greater (63\%), although this study was less focused on identifying unreported exacerbations, which may account for the difference. ${ }^{78}$ Anthonisen criteria has also been demonstrated to relate to exacerbation duration in AATD, with type 1 exacerbations lasting longer than type 2 exacerbations, which were longer than type 3 $(p=0.001) .^{79}$

Untreated exacerbations in AATD are estimated to contribute to $48 \%$ of total exacerbations, similar to rates seen in usual COPD. ${ }^{7,80}$ Patients' perception of unwellness and breathlessness was significantly shorter in untreated versus treated AATD exacerbations, by approximately $80 \%$ and $50 \%$ respectively, implicating their role in patients' decisions to seek additional treatment. ${ }^{7}$ Cold-like symptoms were reported in approximately one-third of AATD COPD exacerbations and coryzal illness was reported as the best independent predictive factor of AATD patients seeking treatment ( $p=0.001)$ according to regression analysis. ${ }^{7,79}$ This may relate to the observation that cold-like symptoms during exacerbations of usual COPD relate to significantly greater falls in FEV $1 \quad(p=0.043)$, compared to exacerbations without such features. ${ }^{20}$ Upperrespiratory tract symptoms at exacerbation are considered to be associated with viral infections, with higher Human rhinovirus (HRV) loads detected in patients with cold-like symptoms or sore throats than those without ( $p=0.046$ and $p=0.006$, respectively). ${ }^{81}$ Colds in the absence of viral infection still predict a worse exacerbation symptom score and are more measurable in clinical terms. ${ }^{82}$

\section{Rate of Exacerbations}

Evaluation of daily diary cards to identify Anthonisen symptoms indicates a median (interquartile range
[IQR]) annualized exacerbation rate of 5.0 episodes (4.0 to 7.0) per patient per year in AATD and 2.5 (1.3 to 3.9) in usual COPD. ${ }^{7,80}$ Median (IQR) exacerbation duration in AATD is reported to be 14 days (7-21), which is approximately double that observed in usual COPD, using studies of similar methodology. ${ }^{78,83}$ Additionally, a higher rate of hospitalized exacerbations can be observed in AATD COPD compared to usual COPD. ${ }^{80,84}$ The difference in severity and slower resolution of exacerbations may relate to inflammatory differences. This is supported by the observation that sputum purulence, which associates with MPO, remained elevated for up to 6 weeks following exacerbation in deficient individuals. ${ }^{7,85}$ Chronic bronchitis is associated with a higher frequency of exacerbations in AATD, which may relate to higher concentrations of IL- 8 and NE in induced sputum of AATD patients who chronically expectorate. $4,78,86$

In a cohort of 87 AATD COPD participants, the proportion of patients experiencing exacerbations each year was consistent across a 3 -year period, although, whether individual exacerbation rates remained consistent was not reported. ${ }^{79}$ Patients experiencing exacerbations in year 1 were more likely to continue having exacerbations in the second and third year ( $p=0.04$ and $p<0.001$, respectively). ${ }^{79}$ The demographics and clinical characteristics of frequent exacerbators in AATD, and the influence of specific COPD phenotypes (e.g., small airways disease) upon rate of exacerbations are not currently known.

\section{Clinical Consequences}

Exacerbations in AATD are implicated in disease progression. ${ }^{8,9}$ Decline in $\mathrm{FEV}_{1}$ is significantly associated with an elevated annual exacerbation rate in AATD individuals. ${ }^{8,84,87,88}$ AATD exacerbations are reported to be of greater impact in patients with more severe lung impairment, which might relate to an observed inverse relationship between baseline $\mathrm{FEV}_{1}$ (percentage of predicted) and change in concentrations of sputum IL-8 and IL-6 at exacerbation. ${ }^{20,79}$ This may be particularly detrimental in AATD, given the higher annual decline in $\mathrm{FEV}_{1}$ observed in AATD patients when compared to usual COPD. ${ }^{8,87-89}$ There is a significant relationship between increased self-reported exacerbation rate and longitudinal deterioration of the St George's Respiratory Questionnaire score, in 
terms of both total score and sub-scales ( $p<0.001$ for all). ${ }^{10}$ In a cohort of AATD patients receiving AAT augmentation therapy, increased exacerbation frequency was demonstrated to relate to significantly lower Short Form-36 Health questionnaire mental composite scores, indicating poorer mental health in frequent exacerbators. ${ }^{90}$ In this case, it is unclear whether pulmonary exacerbations contribute to the development of anxiety and depression or if the reverse is true.

\section{Managing and Preventing Exacerbations}

\section{Acute Management}

\section{Antibiotic Therapy}

The aim of acute management for AECOPD is to minimize the negative impact of the current exacerbation and reduce the occurrence of future events. ${ }^{5}$ Antibiotic therapy is used frequently in usual COPD and treatment guidance often relates to sputum purulence. ${ }^{6}$ Limited evidence suggests that antibiotic therapy in AATD is effective at reducing bacterial load and detectability of pathogens. ${ }^{12}$ Investigations in AATD have shown that exacerbation duration is related to a delay in starting antibiotic treatment, although the period from treatment commencement to exacerbation resolution is unaltered, highlighting the importance of early intervention, potentially via patient rescue packs. ${ }^{79}$

\section{Systemic Corticosteroids}

Oral corticosteroids (OCSs) are recommended for acute management of AECOPD. ${ }^{5}$ There is no published data on OCSs with regards to AATD. In a meta-analysis of usual COPD individuals, OCSs are demonstrated to reduce the risk of treatment failure (odds ratio[OR] 0.48; 95\% confidence interval [CI] 0.35 to 0.67 ) and associate with a lower level of relapse, compared to controls. ${ }^{91}$ These effects are attributed to the multiple actions of (systemic) corticosteroids, including decreased pulmonary inflammation, evidenced by significantly decreased MPO concentrations. ${ }^{92,93}$ However, OCSs significantly increase the likelihood of adverse events (OR 2.33; 95\% CI 1.59 to 3.43), most notably, hyperglycemia. ${ }^{91}$ This may be particularly relevant for AATD individuals, who appear to exacerbate more frequently, as adverse effects of OCSs may follow a cumulative dose-response relationship. ${ }^{7,94,95}$
Therefore, OCS therapy should be targeted to individuals who are most likely to benefit, which has effectively been predicted by eosinophilia (peripheral blood eosinophil count $>2 \%$ ) in usual COPD. ${ }^{96,97}$ AATD and usual COPD have a similar prevalence of eosinophilia (approximately 40\%). ${ }^{98,99}$ However, the efficacy of OCS use in acute management of exacerbations should be tested in an AATD cohort, as pathogenesis between the 2 conditions differ which may impact clinical outcomes.

\section{Reducing Risk of Future Events}

\section{Augmentation Therapy}

Augmentation therapy is effective in reducing the rate of computed tomography-measured lung density decline, though its role in exacerbation is less clear. ${ }^{11}$ In a recent meta-analysis, intravenous infusions of AAT were found to associate with a significantly increased annual exacerbation rate (0.29/year; CI 0.02-0.54; $p=0.02)$, although the primary studies included in this analysis were not appropriately powered to detect differences in exacerbation rate. ${ }^{11,100,101}$ The EXAcerbations and Computed Tomography Scan as Lung Endpoints (EXACTLE) study (included in the meta-analysis) reported no change in exacerbation frequency with augmentation therapy, although it did report a reduction in exacerbation severity. ${ }^{100}$ Conversely, an observational study by Barros-Tizón et al reported a reduction in the mean number of exacerbations per patient and reduced incidence of severe exacerbations during the intravenous augmentation treatment period. ${ }^{102}$ Such observations may relate to decreased LTB4 levels, which can be observed in deficient patients following AAT augmentation, probably as a direct response to decreased NE. ${ }^{46}$ The effect of augmentation therapy on exacerbations would be a useful target of future research.

\section{Inhaled Corticosteroids and Bronchodilators}

Although no specific data in AATD exists, inhaled corticosteroids (ICSs) and bronchodilators are used in the management of AATD COPD. ${ }^{5}$ The role of ICSs in reducing exacerbation rate in usual COPD is clearly demonstrated, both alone and in combination with long-acting beta agonists. ${ }^{7,12,103,104}$ ICS use in usual COPD has been shown to cause a significant reduction in concentration of key inflammatory drivers of AECOPD, including IL-8, TNF-a and mean 
percentages of neutrophils ( $p<0.01$ for all) although changes in LTB4 are repeatedly not observed. ${ }^{105-107}$ ICSs may be particularly beneficial in AATD, where exacerbation rate and inflammation are known to be greater than usual COPD. ${ }^{7,12}$

Evidence of adverse effects of ICSs are also welldocumented, particularly severe pneumonia, which is frequently associated with Pseudomonas aeruginosa infection and results in excess death. ${ }^{108-110}$ It is conceivable that this may be of greater consequence to AATD individuals. This follows observations in transgenic mice that human AAT is protective against mortality due to Pseudomonas aeruginosa pneumonia. ${ }^{111}$ Effectiveness of ICS therapy, as with OCS, may be informed by eosinophilia in usual COPD. ${ }^{99,112}$ Blood eosinophilia has also been suggested in AATD as an indication for ICS use in order to reduce $\mathrm{FEV}_{1}$ decline, which may in turn reduce exacerbation burden. ${ }^{81,113}$ In instances where eosinophilia is absent, or ICS therapy is not successful, long-acting bronchodilators may be effective at reducing exacerbation rate and severity. ${ }^{114}$

\section{Vaccination}

Influenza and pneumococcal vaccinations, PCV13 and PPSV23, are recommended for patients with COPD and are demonstrated to reduce exacerbation rate in usual COPD. 5,115,116 Köhnlein et al observed significantly fewer exacerbations in 267 AATD patients vaccinated against pneumococci, influenza or both $(p=0.01)$, according to a selfreported questionnaire, with a loose definition of exacerbation. ${ }^{117}$ In a larger study of influenza vaccinations, adopting stricter definitions of exacerbations and recorded via telephone interviews, Campos et al reported no significant differences in exacerbation rate or severity in vaccinated AATD patients versus controls. ${ }^{118}$ In fact, where exacerbations were defined according to the definition proposed by Rodriguez-Roisin, Campos et al found that vaccinated patients over 60 years of age experienced significantly more exacerbations compared to controls $(p=0.05)$, although this difference was not observed according to the Anthonisen definition of exacerbation. ${ }^{118,119}$ While discrepancy remains over the efficacy of vaccination in moderating exacerbation occurrence and severity in AATD, recommendations for vaccination in this population are justified based on the efficacy of reducing influenza and invasive pneumococcal disease.

\section{Smoking}

Smoking cessation is associated with a reduced risk of COPD exacerbations, which is related to the duration of abstinence. ${ }^{120}$ In AATD, significantly lower frequencies of exacerbation were observed in PiSZ phenotype individuals compared to PiZZ phenotype individuals in a group of moderate smokers, but these inter-genotypic differences were observed to diminish in the group of intensive smokers, supporting evidence for a role of smoking cessation in controlling exacerbation frequency. ${ }^{84,121}$

\section{Pulmonary Rehabilitation}

Pulmonary rehabilitation (PR) is demonstrated to have favorable effects on re-exacerbation frequency/ severity following AECOPD in usual COPD patients and is also demonstrated to significantly reduce $\mathrm{FEV}_{1}$ decline. ${ }^{122,123}$ In individuals with AATD, PR has shown comparable effectiveness in improving 6-minute walking distance compared to usual COPD individuals. ${ }^{124}$ However, skeletal muscle biopsy showed that muscle adaptation patterns in AATD are suggestive of smaller improvements versus controls, suggesting that the exacerbation benefit of $\mathrm{PR}$ in usual COPD may not be entirely transferable to AATD. ${ }^{125}$

\section{Prophylactic Macrolide Therapy}

Macrolide antibiotics have not been investigated in AATD but have been found to be effective in reducing exacerbation rate in usual COPD compared to placebo (RR 0.58, 95\% CI 0.42-0.79; $p=0.001) .{ }^{126}$ The immunomodulatory effects of macrolides appear to directly oppose the pro-inflammatory milieu which results from deficient AAT, providing a conceivable biochemical mechanism in which macrolides may be of greater efficacy in reducing exacerbation burden in AATD. ${ }^{127}$ Long-term macrolide therapy has been reported to decrease exacerbation frequency in Pseudomonas Aeruginosa colonized CF patients, who have a comparable pulmonary inflammatory environment to AATD individuals. ${ }^{32,128,129}$ Erythromycin has also been demonstrated to prevent rhinovirus infection in cultured human tracheal epithelial cells, potentially via ICAM-1 modulation, suggesting potential in preventing viral 
exacerbations. ${ }^{130}$

\section{Conclusion}

Exacerbations of AATD COPD are known to differ from usual $C O P D$, but the extent and consequence of this is are not entirely known (Table 2). In AATD, exacerbations are demonstrated to be of greater frequency and duration than those in usual COPD, which is likely related to differences in inflammation. Further understanding of the mechanisms by which exacerbations of AATD COPD arise may assist with informing the biochemical rationale for future preventative and acute management strategies for exacerbations. Exacerbations of AATD COPD have a significant negative impact on lung function decline and quality of life. Despite this, there is a lack of targeted research investigating exacerbations in AATD, with particularly limited evidence on the management and prevention of exacerbations.
Accordingly, conventional COPD treatments are used in AATD, despite any substantial evidence indicating their efficacy. Furthermore, the only currently available AATD specific therapy is yet to be proven effective at reducing exacerbation rate. In order to see improvements in patients' quality of life and prognosis, primary research targeted to investigate exacerbations in AATD would be highly beneficial in order to inform more effective management and preventative strategies.

\section{Acknowledgements}

DJS drafted the article, PRE contributed to the draft of the article, AMT conceived and reviewed the article.

\section{Declaration of Interest}

DJS and PRE have no conflicts of interest. AMT has received grants from AstraZeneca, Chiesi Farmaceutici and CSL Behring.

\section{Table 2. Summary of the Known Features of Acute Exacerbation of COPD in Alpha-1 Antitrypsin Deficiency COPD and non-Alpha-1 Antitrypsin Deficiency COPD}

\begin{tabular}{l|l|l}
$\begin{array}{l}\text { Feature of AECOPD } \\
\text { Presentation }\end{array}$ & \multicolumn{1}{|c}{ Non-AATD COPD } & \multicolumn{1}{c}{ AATD COPD } \\
\hline Frequency & $\begin{array}{l}\text { Exacerbation frequency is well reported. } \\
\text { Characteristics and demographics of frequent } \\
\text { exacerbators have been identified }\end{array}$ & $\begin{array}{l}\text { Exacerbation frequency less well known } \\
\text { Characteristics and demographics of } \\
\text { frequent exacerbators are not well reported }\end{array}$ \\
\hline Clinical Consequences & $\begin{array}{l}\text { Effect of exacerbation on disease progression and } \\
\text { QoL outcomes have been extensively reported }\end{array}$ & $\begin{array}{l}\text { Poorly reported relative to non-AATD COPD } \\
\text { Preventative Management }\end{array}$ \\
$\begin{array}{ll}\text { The effectiveness of ICS, bronchodilators, } \\
\text { macrolide therapy, smoking cessation, } \\
\text { vaccination, and pulmonary rehabilitation on } \\
\text { exacerbation outcomes have been extensively } \\
\text { reported }\end{array}$ & $\begin{array}{l}\text { Vaccination and pulmonary rehabilitation } \\
\text { have been moderately investigated } \\
\text { Effects of other treatments are unknown }\end{array}$ \\
\hline Bacterial Etiology & Causative microorganisms have been identified & Currently unknown \\
\hline Viral Etiology & Causative viruses have been identified & Currently unknown \\
\hline Non-infective Etiology & $\begin{array}{l}\text { The effect of comorbidity, air pollution and } \\
\text { seasonal variation on exacerbation outcomes } \\
\text { have been reported }\end{array}$ & Currently unknown \\
\hline Acute Management & $\begin{array}{l}\text { Effectiveness of antibiotics and OCS have been } \\
\text { extensively reported }\end{array}$ & Currently unknown \\
\hline
\end{tabular}

$\mathrm{COPD}=$ chronic obstructive pulmonary disease; $\mathrm{AATD}=$ alpha- 1 antitrypsin deficiency; $\mathrm{AECOPD}=$ acute exacerbation of $\mathrm{COPD}$;

$\mathrm{QoL}=$ quality of life; ICS=inhaled corticosteroids; OCS=oral corticosteroids 


\section{References}

1. Gadek JE, Fells GA, Zimmerman RL, Rennard SI, Crystal RG. Antielastases of the human alveolar structures. implications for the protease-antiprotease theory of emphysema. $J$ Clin Invest. 1981;68(4):889-898. doi: https://doi.org/10.1172/JCI110344

2. Eriksson S. Pulmonary emphysema and alpha-1 antitrypsin deficiency. Acta Medica Scandinavica. 1964;175(2):197-205. doi: https://doi.org/10.1111/j.0954-6820.1964.tb00567.x

3. Parr DG, Guest PG, Reynolds JH, Dowson L, Stockley RA. Prevalence and impact of bronchiectasis in a1-antitrypsin deficiency. Am J Respir Crit Care Med. 2007;176(12):1215-1221. doi: https://doi.org/10.1164/rccm.200703-4890C

4. Dowson LJ, Guest PJ, Stockley RA. The relationship of chronic sputum expectoration to physiologic, radiologic, and health status characteristics in a-1 antitrypsin deficiency (PiZ). Chest. 2002;122(4):1247-1255.

doi: https://doi.org/10.1378/chest.122.4.1247

5. Global Initiative for Chronic Obstructive Lung Disease. Global strategy for the diagnosis, management, and prevention of chronic obstructive pulmonary disease, 2020 report. GOLD website. Published 2019. Accessed 2020. https://www.goldcopd.org

6. Anthonisen NR, Manfreda J, Warren CP, Hershfield ES, Harding GK, Nelson NA. Antibiotic therapy in exacerbations of chronic obstructive pulmonary disease. Ann Intern Med. 201;106(2):196-204. doi: https://doi.org/10.7326/0003-4819-106-2-196

7. Vijayasaratha K, Stockley RA. Reported and unreported exacerbations of COPD: analysis by diary cards. Chest. 2008;133(1):34-41. doi: https://doi.org/10.1378/chest.07-1692

8. Fahndrich S, Bernhard N, Lepper PM, et al. Exacerbations and duration of smoking abstinence are associated with the annual loss of $\mathrm{FEV}_{1}$ in individuals with PiZZ alpha-1 antitrypsin deficiency. Respir Med. 2017;129:8-15.

doi: https://doi.org/10.1016/j.rmed.2017.05.011

9. Soler-Cataluña JJ, Martínez-García MÁ, Román Sánchez P, Salcedo E, Navarro M, Ochando R. Severe acute exacerbations and mortality in patients with chronic obstructive pulmonary disease. Thorax. 2005;60(11):925-931.

doi: https://doi.org/10.1136/thx.2005.040527

10. Bernhard N, Lepper PM, Vogelmeier C, et al. Deterioration of quality of life is associated with the exacerbation frequency in individuals with alpha-1-antitrypsin deficiency - analysis from the German registry. Int J Chron Obstruct Pulmon Dis. 2017;12:1427-1437.

doi: https://doi.org/10.2147/COPD.S130925

11. Edgar RG, Patel M, Bayliss S, Crossley D, Sapey E, Turner AM. Treatment of lung disease in alpha-1 antitrypsin deficiency: a systematic review. Int J Chron Obstruct Pulmon Dis. 2017;12:12951308. doi: https://doi.org/10.2147/COPD.S130440
12. Hill AT, Campbell EJ, Bayley DL, Hill SL, Stockley RA. Evidence for excessive bronchial inflammation during an acute exacerbation of chronic obstructive pulmonary disease in patients with alpha-1 antitrypsin deficiency (PiZ). Am J Respir Crit Care Med. 1999;160(6):1968-1975.

doi: https://doi.org/10.1164/ajrccm.160.6.9904097

13. Lockett AD, KimaniS, Ddungu G, et al. Alpha(1)-antitrypsin modulates lung endothelial cell inflammatory responses to TNF-alpha. Am J Respir Cell Mol Biol. 2013;49(1):143-150. doi: https://doi.org/10.1165/rcmb.2012-0515OC

14. Papi A, Bellettato CM, Braccioni F, et al. Infections and airway inflammation in chronic obstructive pulmonary disease severe exacerbations. Am J Respir Crit Care Med. 2006;173(10):1114-1121. doi: https://doi.org/10.1164/rccm.200506-8590C

15. Anderson HR, Spix C, Medina S, et al. Air pollution and daily admissions for chronic obstructive pulmonary disease in 6 European cities: results from the APHEA project. Eur Respir J. 1997;10(5):10641071. doi: https://doi.org/10.1183/09031936.97.10051064

16. Hansel NN, McCormack MC, Kim V. The effects of air pollution and temperature on COPD. COPD. 2016;13(3):372-379. doi: https://doi.org/10.3109/15412555.2015.1089846

17. Rutten FH, Cramer MM, Lammers JJ, Grobbee DE, Hoes AW. Heart failure and chronic obstructive pulmonary disease: an ignored combination? Eur J Heart Fail. 2006;8(7):706-711. doi: https://doi.org/10.1016/j.ejheart.2006.01.010

18. Rizkallah J, Man SFP, Sin DD. Prevalence of pulmonary embolism in acute exacerbations of COPD: a systematic review and metaanalysis. Chest. 2009;135(3):786-793.

doi: https://doi.org/10.1378/chest.08-1516

19. Sethi S, Evans N, Grant BJ, Murphy TF. New strains of bacteria and exacerbations of chronic obstructive pulmonary disease. $N$ Engl $J$ Med. 2002;347(7):465-471.

doi: https://doi.org/10.1056/NEJMoa012561

20. Wilkinson TM, Hurst JR, Perera WR, Wilks M, Donaldson GC, Wedzicha JA. Effect of interactions between lower airway bacterial and rhinoviral infection in exacerbations of COPD. Chest. 2006;129(2):317324. doi: https://doi.org/10.1378/chest.129.2.317

21. Sethi S, Wrona C, Eschberger K, Lobbins P, Cai X, Murphy TF. Inflammatory profile of new bacterial strain exacerbations of chronic obstructive pulmonary disease. Am J Respir Crit Care Med. 2008;177(5):491-497.

doi: https://doi.org/10.1164/rccm.200708-1234OC

22. Nita I, Hollander C, Westin U, Janciauskiene SM. Prolastin, a pharmaceutical preparation of purified human alpha1-antitrypsin, blocks endotoxin-mediated cytokine release. Respir Res. 2005;6:1212. doi: https://doi.org/10.1186/1465-9921-6-12 
23. Patel IS, Seemungal TA, Wilks M, Lloyd-Owen SJ, Donaldson GC, Wedzicha JA. Relationship between bacterial colonisation and the frequency, character, and severity of COPD exacerbations. Thorax. 2002;57(9):759-764.

doi: https://doi.org/10.1136/thorax.57.9.759

24. Rosell A, Monso E, Soler N, et al. Microbiologic determinants of exacerbation in chronic obstructive pulmonary disease. Arch Intern Med. 2005;165(8):891-897.

doi: https://doi.org/10.1001/archinte.165.8.891

25. Wood AM, Bassford C, Webster D, et al. Vitamin D-binding protein contributes to COPD by activation of alveolar macrophages. Thorax. 2011;66(3):205-210.

doi: https://doi.org/10.1136/thx.2010.140921

26. Hampson JA, Stockley RA, Turner AM. Free light chains: potential biomarker and predictor of mortality in alpha-1-antitrypsin deficiency and usual COPD. Respir Res. 2016;17(1):34.

doi: https://doi.org/10.1186/s12931-016-0348-1

27. Tumkaya M, Atis S, Ozge C, Delialioglu N, Polat G, Kanik A. Relationship between airway colonization, inflammation and exacerbation frequency in COPD. Respir Med. 2007;101(4):729-737. doi: https://doi.org/10.1016/j.rmed.2006.08.020

28. Balbi B, Sangiorgi C, Gnemmi I, et al. Bacterial load and inflammatory response in sputum of alpha-1 antitrypsin deficiency patients with COPD. Int J Chron Obstruct Pulmon Dis. 2019;14:1879-1893.

doi: https://doi.org/10.2147/COPD.S207203

29. Miravitlles M. Exacerbations of chronic obstructive pulmonary disease: when are bacteria important? Eur Respir J. 2002;20(36 suppl):9s-19s. doi: https://doi.org/10.1183/09031936.02.00400302

30. Strange C, Senior RM, Sciurba F, et al. Rationale and design of the genomic research in alpha-1 antitrypsin deficiency and sarcoidosis study. Alpha-1 protocol. Annals ATS. 2015;12(10):1551-1560. doi: https://doi.org/10.1513/AnnalsATS.201503-143OC

31. Ni Y, Shi G, Yu Y, Hao J, Chen T, Song H. Clinical characteristics of patients with chronic obstructive pulmonary disease with comorbid bronchiectasis: a systemic review and meta-analysis. Int $J$ Chron Obstruct Pulmon Dis. 2015;10:1465.

doi: https://doi.org/10.2147/COPD.S83910

32. Birrer P, McElvaney NG, Rudeberg A, et al. Protease-antiprotease imbalance in the lungs of children with cystic fibrosis. Am JRespir Crit Care Med. 1994;150(1):207-213.

doi: https://doi.org/10.1164/ajrccm.150.1.7912987

33. Doring G, Krogh-Johansen H, Weidinger S, Hoiby N. Allotypes of alpha 1-antitrypsin in patients with cystic fibrosis, homozygous and heterozygous for deltaF508. Pediatr Pulmonol. 1994;18(1):3-7. doi: https://doi.org/10.1002/ppul.1950180104

34. Frangolias DD, Ruan J, Wilcox PJ, et al. Alpha 1-antitrypsin deficiency alleles in cystic fibrosis lung disease. Am J Respir Cell Mol Biol. 2003;29(3 Pt 1):390-396.

doi: https://doi.org/10.1165/rcmb.2002-02710C
35. Mahadeva R, Westerbeek RC, Perry DJ, et al. Alpha1-antitrypsin deficiency alleles and the taq-I G->A allele in cystic fibrosis lung disease. Eur Respir J. 1998;11(4):873-879.

doi: https://doi.org/10.1183/09031936.98.11040873

36. Hewitt R, Farne H, Ritchie A, Luke E, Johnston SL, Mallia P. The role of viral infections in exacerbations of chronic obstructive pulmonary disease and asthma. Ther Adv Respir Dis. 2016;10(2):158-174. doi: https://doi.org/10.1177/1753465815618113

37. Wood AM, Harrison RM, Semple S, Ayres JG, Stockley RA. Outdoor air pollution is associated with rapid decline of lung function in a-1antitrypsin deficiency. Occup Environ Med. 2010;67(8):556-561. doi: https://doi.org/10.1136/oem.2009.047589

38. Li J, Sun S, Tang R, et al. Major air pollutants and risk of COPD exacerbations: A systematic review and meta-analysis. Int $J$ Chron Obstruct Pulmon Dis. 2016;11:3079-3091.

doi: https://doi.org/10.2147/COPD.S122282

39. Zhao J, Li M, Wang Z, et al. Role of $\mathrm{PM}(2.5)$ in the development and progression of COPD and its mechanisms. Respir Res. 2019;20(1):120123. doi: https://doi.org/10.1186/s12931-019-1081-3

40. Westerik JA, Metting EI, van Boven JF, Tiersma W, Kocks JW, Schermer TR. Associations between chronic comorbidity and exacerbation risk in primary care patients with COPD. Respir Res. 2017;18(1):31-32.

doi: https://doi.org/10.1186/s12931-017-0512-2

41. Greulich T, Nell C, Hohmann D, et al. The prevalence of diagnosed a-1 antitrypsin deficiency and its comorbidities: results from a large population-based database. Eur Respir J. 2017;49(1):1600154. doi: https://doi.org/10.1183/13993003.00154-2016

42. Gompertz S, O'Brien C, Bayley DL, Hill SL, Stockley RA. Changes in bronchial inflammation during acute exacerbations of chronic bronchitis. Eur Respir J. 2001;17(6):1112-1119. doi: https://doi.org/10.1183/09031936.01.99114901

43. Drost EM, Skwarski KM, Sauleda J, et al. Oxidative stress and airway inflammation in severe exacerbations of COPD. Thorax. 424;60(4):293. doi: https://doi.org/10.1136/thx.2004.027946

44. Walsh DE, Greene CM, Carroll TP, et al. Interleukin-8 up-regulation by neutrophil elastase is mediated by MyD88/IRAK/TRAF-6 in human bronchial epithelium. J Biol Chem. 2001;276(38):35494-35499. doi: https://doi.org/10.1074/jbc.M103543200

45. Hubbard RC, Fells G, Gadek J, Pacholok S, Humes J, Crystal RG. Neutrophil accumulation in the lung in alpha-1 antitrypsin deficiency. Spontaneous release of leukotriene B4 by alveolar macrophages. $J$ Clin Invest. 1991;88(3):891-897. doi: https://doi.org/10.1172/JCI115391

45. Stockley RA, Bayley DL, Unsal I, Dowson LJ. The effect of augmentation therapy on bronchial inflammation in alpha-1 antitrypsin deficiency. Am J Respir Crit Care Med. 2002;165(11):1494-1498. doi: https://doi.org/10.1164/rccm.2109013 
47. O'Dwyer CA, O'Brien ME, Wormald MR, et al. The BLT1 inhibitory function of alpha-1 antitrypsin augmentation therapy disrupts leukotriene B4 neutrophil signaling. J Immunol. 2015;195(8):36283641. doi: https://doi.org/10.4049/jimmunol.1500038

48. Bergin DA, Reeves EP, Hurley $\mathrm{K}$, et al. The circulating proteinase inhibitor alpha-1 antitrypsin regulates neutrophil degranulation and autoimmunity. Sci Transl Med. 2014;6(217):217ra1.

doi: https://doi.org/10.1126/scitranslmed.3007116

49. Jonigk D, Al-Omari M, Maegel L, et al. Anti-inflammatory and immunomodulatory properties of alpha-1- ntitrypsin without inhibition of elastase. Proc Natl Acad Sci U S A. 2013;110(37):1500715012. doi: https://doi.org/10.1073/pnas.1309648110

50. Woolhouse IS, Bayley DL, Stockley RA. Sputum chemotactic activity in chronic obstructive pulmonary disease: effect of alpha(1)-antitrypsin deficiency and the role of leukotriene $\mathrm{B}(4)$ and interleukin 8. Thorax. 2002;57(8):709-714.

doi: https://doi.org/10.1136/thorax.57.8.709

51. Beeh KM, Kornmann O, Buhl R, Culpitt SV, Giembycz MA, Barnes PJ. Neutrophil chemotactic activity of sputum from patients with COPD: role of interleukin 8 and leukotriene B4. Chest. 2003;123(4):12401247. doi: https://doi.org/10.1378/chest.123.4.1240

52. Bergin DA, Reeves EP, Meleady P, et al. Alpha-1 antitrypsin regulates human neutrophil chemotaxis induced by soluble immune complexes and IL-8. J Clin Invest. 2010;120(12):4236-4250.

doi: https://doi.org/10.1172/JCI41196

53. Stone H, McNab G, Wood AM, Stockley RA, Sapey E. Variability of sputum inflammatory mediators in COPD and a-1 antitrypsin deficiency. Eur Respir J. 2012;40(3):561-569.

doi: https://doi.org/10.1183/09031936.00162811

54. Burnett D, Chamba A, Hill SL, Stockley RA. Neutrophils from subjects with chronic obstructive lung disease show enhanced chemotaxis and extracellular proteolysis. Lancet. 1987;2(8567):1043-1046. doi: https://doi.org/10.1016/S0140-6736(87)91476-0

55. Janciauskiene $\mathrm{S}$, Wrenger $\mathrm{S}$, Immenschuh $\mathrm{S}$, et al. The multifaceted effects of Alpha-1 antitrypsin on neutrophil functions. Front Pharmacol. 2018;9:341. doi: https://doi.org/10.3389/fphar.2018.00341

56. AaronSD, AngelJB, Lunau M, etal. Granulocyteinflammatorymarkers and airway infection during acute exacerbation of chronic obstructive pulmonary disease. Am J Respir Crit Care Med. 2001;163(2):349-355. doi: https://doi.org/10.1164/ajrccm.163.2.2003122

57. Mukhopadhyay S, Hoidal JR, Mukherjee TK. Role of TNFa in pulmonary pathophysiology. Respir Res. 2006;7(1):125. doi: https://doi.org/10.1186/1465-9921-7-125

58. Berkow RL, Wang D, Larrick JW, Dodson RW, Howard TH. Enhancement of neutrophil superoxide production by preincubation with recombinant human tumor necrosis factor. $J$ Immunol. 1987;139(11):3783-3791.
59. Osawa Y, Nagaki M, Banno Y, et al. Tumor necrosis factor alpha-induced interleukin-8 production via NF-kappaB and phosphatidylinositol 3-kinase/akt pathways inhibits cell apoptosis in human hepatocytes. Infect Immun. 2002;70(11):6294-6301. doi: https://doi.org/10.1128/IAI.70.11.6294-6301.2002

60. Churg A, Wang X, Wang RD, Meixner SC, Pryzdial EL, Wright JL. Alpha-1 antitrypsin suppresses TNF-alpha and MMP-12 production by cigarette smoke-stimulated macrophages. Am J Respir Cell Mol Biol. 2007;37(2):144-151. doi: https://doi.org/10.1165/rcmb.2006-0345OC

61. Aaron SD, Vandemheen KL, Maltais F, et al. TNFa antagonists for acute exacerbations of COPD: a randomised double-blind controlled trial. Thorax. 2013;68(2):142-148.

doi: https://doi.org/10.1136/thoraxjnl-2012-202432

62. Ji J, Su L, Liu Z. Critical role of calpain in inflammation. Biomed Rep. 2016;5(6):647-652. doi: https://doi.org/10.3892/br.2016.785

63. Al-Omari M, Korenbaum E, Ballmaier M, et al. Acute-phase protein alpha-1 antitrypsin inhibits neutrophil calpain I and induces random migration. Mol Med. 2011;17(9-10):865-874.

doi: https://doi.org/10.2119/molmed.2011.00089

64. Cuzzocrea S, McDonald MC, Mazzon E, et al. Calpain inhibitor I reduces the development of acute and chronic inflammation. Am J Pathol. 2000;157(6):2065-2079. doi: https://doi.org/10.1016/S0002-9440(10)64845-6

65. Dutra FF, Bozza MT. Heme on innate immunity and inflammation. Front Pharmacol. 2014;5:115. doi: https://doi.org/10.3389/fphar.2014.00115

66. Janciauskiene S, Tumpara S, Wiese M, et al. Alpha-1 antitrypsin binds hemin and prevents oxidative activation of human neutrophils: putative pathophysiological significance. J Leukoc Biol. 2017;102(4):1127-1141.

doi: https://doi.org/10.1189/jlb.3A0317-124R

67. Bradley LM, Douglass MF, Chatterjee D, Akira S, Baaten BJ. Matrix metalloprotease 9 mediates neutrophil migration into the airways in response to influenza virus-induced toll-like receptor signaling. PLOS Pathog. 2012;8(4):e1002641. doi: https://doi.org/10.1371/journal.ppat.1002641

68. Moreno JA, Ortega-Gomez A, Rubio-Navarro A, et al. High-density lipoproteins potentiate alpha- 1 antitrypsin therapy in elastase-induced pulmonary emphysema. Am J Respir Cell Mol Biol. 2014;51(4):536549. doi: https://doi.org/10.1165/rcmb.2013-0103OC

69. Russell RE, Culpitt SV, DeMatos C, et al. Release and activity of matrix metalloproteinase- 9 and tissue inhibitor of metalloproteinase-1 by alveolar macrophages from patients with chronic obstructive pulmonary disease. Am J Respir Cell Mol Biol. 2002;26(5):602-609. doi: https://doi.org/10.1165/ajrcmb.26.5.4685 
70. Lappalainen U, Whitsett JA, Wert SE, Tichelaar JW, Bry K. Interleukin-1beta causes pulmonary inflammation, emphysema, and airway remodeling in the adult murine lung. Am J Respir Cell Mol Biol. 2005;32(4):311-318.

doi: https://doi.org/10.1165/rcmb.2004-03090C

71. Bucurenci N, Blake DR, Chidwick K, Winyard PG. Inhibition of neutrophil superoxide production by human plasma alpha-1 antitrypsin. FEBS Lett. 1992;300(1):21-24.

doi: https://doi.org/10.1016/0014-5793(92)80156-B

72. Li Z, Alam S, Wang J, Sandstrom CS, Janciauskiene S, Mahadeva R. Oxidized \{alpha\}1-antitrypsin stimulates the release of monocyte chemotactic protein-1 from lung epithelial cells: potential role in emphysema. Am J Physiol Lung Cell Mol Physiol. 2009;297(2):388. doi: https://doi.org/10.1152/ajplung.90373.2008

73. Taggart C, Cervantes-Laurean D, Kim G, et al. Oxidation of either methionine 351 or methionine 358 in alpha- 1 antitrypsin causes loss of anti-neutrophil elastase activity. J Biol Chem. 2000;275(35):2725827265. doi: https://doi.org/10.1074/jbc.M004850200

74. Mulgrew AT, Taggart CC, Lawless MW, et al. $Z$ alpha-1 antitrypsin polymerizes in the lung and acts as a neutrophil chemoattractant. Chest. 2004;125(5):1952-1957.

doi: https://doi.org/10.1378/chest.125.5.1952

75. Crisford H, Sapey E, Stockley RA. Proteinase 3; a potential target in chronic obstructive pulmonary disease and other chronic inflammatory diseases. Respir Res. 2018;19(1):180. doi: https://doi.org/10.1186/s12931-018-0883-Z

76. Rao NV, Wehner NG, Marshall BC, Gray WR, Gray BH, Hoidal JR. Characterization of proteinase-3 (PR-3), a neutrophil serine proteinase. structural and functional properties. JBiol Chem. 1991;266(15):95409548.

doi: https://doi.org/10.1016/S0021-9258(18)92854-1

77. Murphy MP, McEnery T, McQuillan K, et al. A1 antitrypsin therapy modulates the neutrophil membrane proteome and secretome. Eur Respir J. 2020;55(4):1901678.

doi: https://doi.org/10.1183/13993003.01678-2019

78. Needham M, Stockley R. Exacerbations in alpha-1 antitrypsin deficiency. Eur Respir J. 2005;25(6):992-1000.

doi: https://doi.org/10.1183/09031936.05.00074704

79. Vijayasaratha K, Stockley RA. Relationship between frequency, length, and treatment outcome of exacerbations to baseline lung function and lung density in alpha-1 antitrypsin-deficient COPD. Int $J$ Chron Obstruct Pulmon Dis. 2012;7:789-796.

doi: https://doi.org/10.2147/COPD.S31797

80. Donaldson GC, Seemungal TA, Patel IS, Lloyd-Owen SJ, Wilkinson TM, Wedzicha JA. Longitudinal changes in the nature, severity and frequency of COPD exacerbations. Eur Respir J. 2003;22(6):931-936. doi: https://doi.org/10.1183/09031936.03.00038303
81. George SN, Garcha DS, Mackay AJ, et al. Human rhinovirus infection during naturally occurring COPD exacerbations. Eur Respir J. 2014;44(1):87-96.

doi: https://doi.org/10.1183/09031936.00223113

82. Johnston NW, Olsson M, Edsbäcker S, et al. Colds as predictors of the onset and severity of COPD exacerbations. Int J Chron Obstruct Pulmon Dis. 2017;12:839-848.

doi: https://doi.org/10.2147/COPD.S127146

83. Seemungal TA, Donaldson GC, Bhowmik A, Jeffries DJ, Wedzicha JA. Time course and recovery of exacerbations in patients with chronic obstructive pulmonary disease. Am J Respir Crit Care Med. 2000;161(5):1608-1613.

doi: https://doi.org/10.1164/ajrccm.161.5.9908022

84. Hiller AM, Piitulainen E, Jehpsson L, Tanash H. Decline in $\mathrm{FEV}_{1}$ and hospitalized exacerbations in individuals with severe alpha-1 antitrypsin deficiency. Int JChron Obstruct Pulmon Dis. 2019;14:10751083. doi: https://doi.org/10.2147/COPD.S195847

85. Stockley RA, Bayley D, Hill SL, Hill AT, Crooks S, Campbell EJ. Assessment of airway neutrophils by sputum colour: correlation with airways inflammation. Thorax. 2001;56(5):366-372. doi: https://doi.org/10.1136/thorax.56.5.366

86. Gompertz S, Hill AT, Bayley DL, Stockley RA. Effect of expectoration on inflammation in induced sputum in alpha-1 antitrypsin deficiency. Respir Med. 2006;100(6):1094-1099.

doi: https://doi.org/10.1016/j.rmed.2005.09.024

87. Dawkins PA, Dawkins CL, Wood AM, Nightingale PG, Stockley JA, Stockley RA. Rate of progression of lung function impairment in a-1 antitrypsin deficiency. Eur Respir J. 2009;33(6):1338-1344. doi: https://doi.org/10.1183/09031936.00061208

88. Downson LJ, Guest PJ, Stockley RA. Longitudinal changes in physiological, radiological, and health status measurements in a1antitrypsin deficiency and factors associated with decline. Am J Respir Crit Care Med. 2001;164(10):1805-1809.

doi: https://doi.org/10.1164/ajrccm.164.10.2106036

89. Vestbo J, Edwards LD, Scanlon PD, et al. Changes in forced expiratory volume in 1 second overtime in COPD. $N$ Engl $J$ Med. 2011;365(13):1184-1192.

doi: https://doi.org/10.1056/NEJMoa1105482

90. Campos MA, Alazemi S, Zhang G, et al. Exacerbations in subjects with alpha-1 antitrypsin deficiency receiving augmentation therapy. Respir Med. 2009;103(10):1532-1539. doi: https://doi.org/10.1016/j.rmed.2009.04.008

91. Walters J, Tan DJ, White CJ, Gibson PG, Wood-Baker R, Walters EH. Systemic corticosteroids for acute exacerbations of chronic obstructive pulmonary disease. Cochrane Database Syst Rev. 2014(9). doi: https://doi.org/10.1002/14651858.CD001288.pub4 
92. Falk JA, Minai OA, Mosenifar Z. Inhaled and systemic corticosteroids in chronic obstructive pulmonary disease. Proc Am Thorac Soc. 2008;5(4):506-512.

doi: https://doi.org/10.1513/pats.200707-096ET

93. Barczyk A, Sozañska E, Trzaska M, Pierzchala W. Decreased levels of myeloperoxidase in induced sputum of patients with COPD after treatment with oral glucocorticoids. Chest. 2004;126(2):389-393. doi: https://doi.org/10.1378/chest.126.2.389

94. Price DB, Trudo F, Voorham J, et al. Adverse outcomes from initiation of systemic corticosteroids for asthma: long-term observational study. J Asthma Allergy. 2018;11:193-204. doi: https://doi.org/10.2147/JAA.S176026

95. Walsh L, Wong CA, Oborne J, et al. Adverse effects of oral corticosteroids in relation to dose in patients with lung disease. Thorax. 2001;56(4):279-284.

doi: https://doi.org/10.1136/thorax.56.4.279

96. Bafadhel M, McKenna S, Terry S, et al. Blood eosinophils to direct corticosteroid treatment of exacerbations of chronic obstructive pulmonary disease: a randomized placebo-controlled trial. Am J Respir Crit Care Med. 2012;186(1):48-55.

doi: https://doi.org/10.1164/rccm.201108-15530C

97. Sivapalan P, Lapperre TS, Janner J, et al. Eosinophil-guided corticosteroid therapy in patients admitted to hospital with COPD exacerbation (CORTICO-COP): a multicentre, randomised, controlled, open-label, non-inferiority trial. Lancet Respir Med. 2019;7(8):699709. doi: https://doi.org/10.1016/S2213-2600(19)30176-6

98. Zaffarullah S, Turner AM, Stockley R, Griffiths D, Edgar R. Blood eosinophils as a biomarker in alpha-1 antitrypsin deficiency. Eur Respir J. 2015;46(suppl 59):PA3351.

doi: https://doi.org/10.1183/13993003.congress-2015.PA3351

99. Singh D, Kolsum U, Brightling CE, Locantore N, Agusti A, Tal-Singer R. Eosinophilic inflammation in COPD: prevalence and clinical characteristics. Eur Respir J. 2014;44(6):1697-1700. doi: https://doi.org/10.1183/09031936.00162414

100. Dirksen A, Piitulainen E, Parr DG, et al. Exploring the role of CT densitometry: a randomised study of augmentation therapy in a1antitrypsin deficiency. Eur Respir J. 2009;33(6):1345-1353. doi: https://doi.org/10.1183/09031936.00159408

101. Chapman KR, Burdon JGW, Piitulainen E, et al. Intravenous augmentation treatment and lung density in severe a1 antitrypsin deficiency (RAPID): a randomised, double-blind, placebo-controlled trial. Lancet. 2015;386(9991):360-368.

doi: https://doi.org/10.1016/S0140-6736(15)60860-1

$\overline{\text { 102. Barros-Tizón JC, Torres ML, Blanco I, Martinez MT, Investigators }}$ of the rEXA study group. Reduction of severe exacerbations and hospitalization-derived costs in alpha-1 antitrypsin-deficient patients treated with alpha-1 antitrypsin augmentation therapy. Ther Adv Respir Dis. 2012;6(2):67-78.

doi: https://doi.org/10.1177/1753465812438387
103. Burge PS, Calverley PM, Jones PW, Spencer S, Anderson JA, Maslen TK. Randomised, double blind, placebo-controlled study of fluticasone propionate in patients with moderate to severe chronic obstructive pulmonary disease: the ISOLDE trial. BMJ. 2000;320(7245):12971303. doi: https://doi.org/10.1136/bmj.320.7245.1297

104. Calverley PM, Anderson JA, Celli B, et al. Salmeterol and fluticasone propionate and survival in chronic obstructive pulmonary disease. $N$ Engl J Med. 2007;356(8):775-789. doi: https://doi.org/10.1056/NEJMoa063070

105. Ozol D, Aysan T, Solak ZA, Mogulkoc N, Veral A, Sebik F. The effect of inhaled corticosteroids on bronchoalveolar lavage cells and IL-8 levels in stable COPD patients. Respir Med. 2005;99(12):1494-1500. doi: https://doi.org/10.1016/j.rmed.2005.04.025

106. Basyigit I, Yildiz F, Ozkara SK, Yildirim E, Boyaci H, Ilgazli A. Addition of inhaled corticosteroid on combined bronchodilator therapy in patients with COPD. Pulm Pharmacol Ther. 2005;18(6):422-426. doi: https://doi.org/10.1016/j.pupt.2005.03.005

107. Montuschi P, Kharitonov SA, Ciabattoni G, Barnes PJ. Exhaled leukotrienes and prostaglandins in COPD. Thorax. 2003;58(7):585588. doi: https://doi.org/10.1136/thorax.58.7.585

108. Crim C, Calverley PMA, Anderson JA, et al. Pneumonia risk in COPD patients receiving inhaled corticosteroids alone or in combination: TORCH study results. Eur Respir J. 2009;34(3):641-647. doi: https://doi.org/10.1183/09031936.00193908

109. Eklöf J, Ingebrigtsen TS, Soerensen R, et al. Use of inhaled corticosteroids and risk of acquiring pseudomonas aeruginosa in patients with chronic obstructive pulmonary disease. Am J Respir Crit Care Med. 2020:A2488. doi: https://doi.org/10.1164/ajrccmconference.2020.201.1_MeetingAbstracts.A2488

110. Drummond MB, Dasenbrook EC, Pitz MW, Murphy DJ, Fan E. Inhaled corticosteroids in patients with stable chronic obstructive pulmonary disease: a systematic review and meta-analysis. JAMA. 2008;300(20):2407-2416.

doi: https://doi.org/10.1001/jama.2008.717

111. Pott GB, Beard KS, Bryan CL, Merrick DT, Shapiro L. Alpha-1 antitrypsin reduces severity of pseudomonas pneumonia in mice and inhibits epithelial barrier disruption and pseudomonas invasion of respiratory epithelial cells. Front Public Health. 2013;1:19. doi: https://doi.org/10.3389/fpubh.2013.00019

112. Watz H, Tetzlaff K, Wouters EF, et al. Blood eosinophil count and exacerbations in severe chronic obstructive pulmonary disease after withdrawal of inhaled corticosteroids: a post-hoc analysis of the WISDOM trial. Lancet Respir Med. 2016;4(5):390-398. doi: https://doi.org/10.1016/S2213-2600(16)00100-4

113. Low EV, Hughes SM, Zaffarullah S, Kantas D, Stockley RA, Turner AM. ICS use may modify $\mathrm{FEV}_{1}$ decline in a1-antitrypsin deficiency patients with relatively high blood eosinophils. Respiration. 2018;95(2):114121.

doi: https://doi.org/10.1159/000481867 
114. Vogelmeier C, Hederer B, Glaab T, et al. Tiotropium versus salmeterol for the prevention of exacerbations of COPD. $N$ Engl $J$ Med. 2011;364(12):1093-1103.

doi: https://doi.org/10.1056/NEJMoa1008378

$\overline{\text { 115. Poole PJ, Chacko E, Wood-Baker RW, Cates CJ. Influenza vaccine }}$ for patients with chronic obstructive pulmonary disease. Cochrane Database Syst Rev. 2006;(1):CD002733. doi: https://doi.org/10.1002/14651858.CD002733.pub2

116. Walters JA, Tang JN, Poole P, Wood-Baker R. Pneumococcal vaccines for preventing pneumonia in chronic obstructive pulmonary disease. Cochrane Database Syst Rev. 2017;1(1):CD001390. doi: https://doi.org/ 10.1002/14651858.CD001390.pub4

117. Köhnlein T, Janciauskiene S, Welte T. Diagnostic delay and clinical modifiers in alpha-1 antitrypsin deficiency. Ther Adv Respir Dis. 2010;4(5):279-287.

doi: https://doi.org/10.1177/1753465810376407

118. Campos MA, Alazemi S, Zhang G, Sandhaus RA, Wanner A. Influenza vaccination in subjects with a1-antitrypsin deficiency. Chest. 2008;133(1):49-55.

doi: https://doi.org/10.1378/chest.07-1482

119. Rodriguez-Roisin R. Toward a consensus definition for COPD exacerbations. Chest. 2000;117(5 Suppl 2):398S-401S. doi: https://doi.org/10.1378/chest.117.5_suppl_2.398S

120. Au DH, Bryson CL, Chien JW, et al. The effects of smoking cessation on the risk of chronic obstructive pulmonary disease exacerbations. $J$ Gen Intern Med. 2009;24(4):457-463. doi: https://doi.org/10.1007/s11606-009-0907-y

121. Bernhard N, Lepper PM, Vogelmeier C, et al. Intensive smoking diminishes the differences in quality of life and exacerbation frequency between the alpha-1 antitrypsin deficiency genotypes PiZZ and PiSZ. Respir Med. 2017;130:1-8. doi: https://doi.org/10.1016/j.rmed.2017.07.004

122. Seymour JM, Moore L, Jolley CJ, et al. Outpatient pulmonary rehabilitation following acute exacerbations of COPD. Thorax. 2010;65(5):423-428.

doi: https://doi.org/10.1136/thx.2009.124164

123. Incorvaia C, Russo A, Foresi A, et al. Effects of pulmonary rehabilitation on lung function in chronic obstructive pulmonary disease: the FIRST study. Eur J Phys Rehabil Med. 2014;50(4):419-426

124. Jarosch I, Hitzl W, Koczulla AR, et al. Comparison of exercise training responses in COPD patients with and without alpha-1 antitrypsin deficiency. Respir Med. 2017;130:98-101. doi: https://doi.org/10.1016/j.rmed.2017.07.009

125. Jarosch I, Gehlert S, Jacko D, et al. Different training-induced skeletal muscle adaptations in COPD patients with and without alpha-1 antitrypsin deficiency. Respiration. 2016;92(5):339-347.

doi: https://doi.org/10.1159/000449509
126. Uzun S, Djamin RS, Kluytmans JA, et al. Azithromycin maintenance treatment in patients with frequent exacerbations of chronic obstructive pulmonary disease (COLUMBUS): a randomised, doubleblind, placebo-controlled trial. Lancet Respir Med. 2014;2(5):361-368. doi: https://doi.org/10.1016/S2213-2600(14)70019-0

127. Martinez FJ, Curtis JL, Albert R. Role of macrolide therapy in chronic obstructive pulmonary disease. Int $J$ Chron Obstruct Pulmon Dis. 2008;3(3):331-350. doi: https://doi.org/10.2147/COPD.S681

128. Rogers GB, Bruce KD, Martin ML, Burr LD, Serisier DJ. The effect of long-term macrolide treatment on respiratory microbiota composition in non-cystic fibrosis bronchiectasis: an analysis from the randomised, double-blind, placebo-controlled BLESS trial. Lancet Respir Med. 2014;2(12):988-996. doi: https://doi.org/10.1016/S2213-2600(14)70213-9

129. Saiman L, Marshall BC, Mayer-Hamblett N, et al. Azithromycin in patients with cystic fibrosis chronically infected with pseudomonas aeruginosa: a randomized controlled trial. JAMA. 2003;290(13):17491756. doi: https://doi.org/10.1001/jama.290.13.1749

130. Suzuki T, Yamaya M, Sekizawa K, et al. Erythromycin inhibits rhinovirus infection in cultured human tracheal epithelial cells. Am J Respir Crit Care Med. 2002;165(8):1113-1118. doi: https://doi.org/ 10.1164/ajrccm.165.8.2103094 